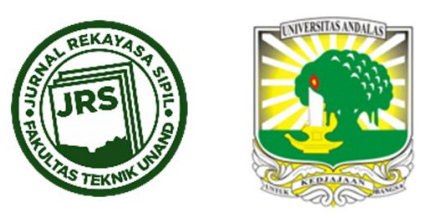

\title{
PENGARUH RASA TAKUT TERHADAP PROFIL PERILAKU PENGENDARA USIA REMAJA: STUDI DENGAN DRIVER BEHAVIOUR QUESTIONNAIRE (DBQ)
}

\author{
FARDZANELA SUWARTO ${ }^{1 *}$, HARTONO $^{1}$, LUKMAN $^{1}$ \\ ${ }^{1}$ Teknik Sipil,Sekolah Vokasi, Universitas Diponegoro \\ *Corresponding author: $\triangle$ fardzanela@live.undip.ac.id
}

Naskah diterima : 5 Maret 2019. Disetujui: 31 November 2019.

\begin{abstract}
ABSTRAK
Di Kota Semarang jumlah kecelakaan lalu lintas cenderung mengalami kenaikan setiap tahunnya. Dari seluruh kecelakaan yang terjadi di jalan raya, faktor perilaku pengemudi ( $h$ uman error) memiliki kontribusi paling tinggi yaitu mencapai antara 80-90 persen. Kecelakaan jalan menjadi penyebab utama kematian di kalangan remaja antara usia 14 dan 24 tahun. Hal ini disebabkan oleh beberapa faktor salah satunya persepsi pengendara. Tujuan studi ini adalah untuk melihat kecenderungan perilaku dan pengaruh faktor persepsi rasa takut dalam mempengaruhi perilaku pengemudi usia remaja di Kota Semarang, agar didapatkan pemahaman yang lebih dalam tentang perilaku pengemudi remaja dalam upaya mengurangi jumlah kecelakaan lalu lintas. Responden pengendara kendaraan usia remaja akan diminta untuk melengkapi Driver Behaviour Questionnaire(DBQ) yang meminta mereka untuk menilai frekuensi dimana mereka melakukan berbagai jenis kesalahan dan pelanggaran saat berkendara serta kuesioner persepsi rasa takut dalam berkendara. Dari Penelitian ini dapat disimpulkan bahwa persepsi terhadap rasa takut tidak memiliki hubungan yang cukup kuat terhadap keterampilan mengemudi pengendara usia remaja terlihat dari nilai korelasi Rsquare kedua variabel tersebut yaitu sebesar $1.1 \%$. Selain itu persepsi rasa takut yang juga tidak dapat serta merta mengurangi tingkat kesalahan (lapses dan error) yang dapat dibuat tiap individu saat sedang berkendara, tetapi perasaan takut ini dapat mengurangi intensi atau keinginan pengendara remaja untuk melakukan tindakan pelanggaran ringan maupun berat (ordinary dan aggressive violations).
\end{abstract}

Kata kunci : kecelakaan, pengemudi, usia remaja, DBQ, rasa takut

\section{PENDAHULUAN}

Peran sektor transportasi sangat penting di Kota Semarang sebagai ibu kota propinsi Jawa Tengah yang selain berfungsi sebagai pusat pengendalian pemerintahan juga berfungsi sebagai kota perdagangan, pendidikan, industri, dan kota wisata. Keadaan tersebut mengakibatkan kegiatan di dalam Kota Semarang cukup tinggi, sehingga menyebabkan tidak maksimalnya manajemen dan pengaturan lalu lintas di Kota Semarang. Dengan 
kondisi penyediaan jalan dan permintaan yang timpang dan tidak disertai dengan manajemen transportasi dan lalu lintas serta pemantapan ketertiban berlalu lintas maka keselamatan lalu lintas menjadi sangat sulit diwujudkan, padahal keselamatan dalam transportasi merupakan hal yang tidak boleh dikesampingkan.

Di Kota Semarang jumlah kecelakaan lalu lintas cenderung mengalami kenaikan setiap tahunnya. Jumlah kecelakaan yang terjadi pada tahun 2013 adalah sebanyak 957 kejadian dengan nilai kerugian mencapai Rp 1.438.200.00,-. Dari seluruh kecelakaan yang terjadi di jalan raya, faktor perilaku pengemudi ( human error) memiliki kontribusi paling tinggi yang diakibatkan oleh beberapa faktor yaitu kecepatan kendaraan, perangai pengemudi, dan persepsi. Salah satu program intervensi untuk menekan angka kecelakaan pada kelompok pengemudi usia remaja yaitu dengan dengan iklan layanan masyarakat yang bertujuan meningkatkan persepsi tentang rasa takut. Namun belum terdapat kajian apakah jenis intervensi ini telah tepat dilakukan pada kelompok pengemudi usia remaja, yaitu dapat dilihat dari hubungan rasa takut dengan perilaku mengemudi pengendara. Serta belum adanya kesimpulan tentang bagaimana rasa takut mempengaruhi bukan hanya perilaku mengemudi namun juga keterampilan mengemudi pada pengemudi usia remaja. Hal tersebut melatarbelakangi penelitian ini untuk melihat kecenderungan perilaku dan pengaruh faktor rasa takut dalam mempengaruhi keterampilan mengemudi pada pengemudi usia remaja di Kota Semarang. Sehingga tujuan dari penelitian ini adalah untuk mengukur hubungan persepsi rasa takut dalam berkendara terhadap sikap mengemudi pada pengemudi usia remaja.

\section{KECELAKAAN LALU LINTAS DAN RASA TAKUT}

\subsection{Faktor Penyebab Kecelakaan}

Beberapa kendala dalam mencapai keadaan lalu lintas yang aman salah satu nya adalah disebabkan oleh tercampurnya penggunaan jalan dan tata guna lahan di sekitarnya (mixed traffic). Faktor mixed traffic tersebut dapat mengakibatkan peningkatan jumlah kecelakaan lalu lintas.

Secara umum ada tiga faktor utama penyebab kecelakaan; Faktor Pengemudi (Road User), Faktor Kendaraan (Vehicle), Faktor Lingkungan Jalan (Road Environment). Pada dasarnya faktor-faktor tersebut berkaitan atau saling menunjang bagi terjadinya kecelakaan. Namun, dengan diketahuinya faktor penyebab kecelakaan yang utama dapat ditentukan langkahlangkah penanggulangan untuk menurunkan jumlah kecelakaan. Menurut Pignataro (1973) menyatakan kecelakaan diakibatkan oleh kombinasi dari beberapa faktor perilaku buruk dari pengemudi ataupun pejalan kaki, jalan, kendaraan, pengemudi ataupun pejalan kaki, cuaca buruk ataupun pandangan yang buruk. Faktor perilaku pengemudi (human error) memiliki kontribusi paling tinggi yaitu mencapai antara 80-90 persen (Tight, 2012). Hal ini disebabkan oleh beberapa faktor salah satunya yaitu perilaku pengendara dan kurang teredukasinya pengendara (Petridou \& Moustaki, 2001).

Sejumlah penelitian telah melaporkan bahwa remaja memiliki risiko lebih tinggi dalam mengalami kecelaaan lalu lintas (Sullman, Thomas, \& Stephens, 2012). Salah satu alasan mengapa risiko yang meningkat ini adalah remaja memainkan berbagai perilaku on-road yang tidak aman dan berpotensi berisiko yang meningkatkan risiko meninggal atau terluka di jalan (Poudel-Tandukar, Nakahara, Ichikawa, Poudel, \& Wakai, 2006);(Elliott \& Baughan, 2004);(Sullman \& Mann, 2009). Ngebut / melampaui batas kecepatan (Klauer et al., 2011) dan perilaku mengemudi berisiko lainnya terlihat tinggi, dan mungkin meningkat, pada tahun-tahun awal mengemudi (Simons-Morton et al., 2011). Kemudian (Mosedale, 
Purdy, \& Clarkson, 2004) menyimpulkan bahwa faktor yang paling sering berperan dalam menyebabkan kecelakaan adalah terlambat menghindari obyek di jalan sebanyak $28 \%$, kehilangan kontrol kedaraan (19\%) dan gagal menberikan jalan bagi kendaraan lain di jalan yang lebih utama (15\%).

Dari studi - studi yang telah banyak dilakukan tersebut, dapat disimpulkan bahwa faktor manusia memiliki andil yang paling besar dalam menyebabkan kecelakaan lalu lintas. Selain itu Nelson (1969) menyatakan menyatakan bahwa peraturan keamanan telah dilakukan oleh para pembuat kendaraan dan kondisi jalan telah ditingkatkan, tetapi pengemudi tetap saja masih melakukan kesalahan. Salah satu faktor manusia yang berpengaruh disini yaitu diakibatkan oleh persepsi.

\subsection{Persepsi Terhadap Rasa Takut}

Salah satu hal yang mempengaruhi perilaku pengendara usia remaja adalah kestabilan emosi. Kestabilan emosi merupakan kecenderungan ke arah emosionalitas yang dapat menyebabkan perubahan suasana hati (Mowen, Harris, \& Bone, 2004);(D'Souza \& Tay, 2016). Pengendara usia remaja cenderung memiliki suasana hati yang mudah berubah yang dapat diakibatkan oleh perubahan situasi. Salah satu faktor yang dapat mempengaruhi kestabilan emosi pengendara adalah persepsi tentang rasa takut (Siska \& Cokki, 2017). Rasa takut merupakan sebuah respon terhadap ketidakpastian dan ancaman (Passyn \& Sujan, 2006). Selain itu menurut Coleman, Williams, Morales, and White (2017) rasa takut adalah suatu komponen sistem manajemen ancaman yang dapat membantu sesorang bertahan dalam persoalan hidup dan mati. Beberapa hubungan antara rasa takut terhadap perilaku pengendara telah disebutkan seperti oleh Schmidt-Daffy (2013) bahwa perilaku berkendara dapat terpengaruh dari rasa takut maupun rasa cemas, pemahaman tentang perbedaan emosi ini dapat membantu dalam mengembangkan langkah-langkah peningkatan keselamatan jalan. Rasa takut juga dapat meningkatkan persepsi risiko pengendara (Lu, Xie, \& Zhang, 2013). Selain itu emosi pada rasa takut akan membuat pengendara motor mempersepsi bahaya secara lebih cepat daripada pengendara yang tidak merasakan emosi takut (Surya \& Bagaskara, 2016).

Belum adanya studi tentang bagaimana rasa takut mempengaruhi bukan hanya perilaku mengemudi namun juga keterampilan mengemudi pada pengemudi usia remaja melatarbelakangi penelitian ini untuk melihat kecenderungan perilaku dan pengaruh faktor rasa takut dalam mempengaruhi keterampilan mengemudi yang diukur dengan Driver Behaviour.

\subsection{The Driver Behaviour Questionnaire (DBQ)}

Penelitian ini mengunakan Kuesioner Perilaku Pengemudi atau The Driver Behavior Questionnaire $(D B Q)$ untuk mengetahui kecenderungan sifat dan ketrampilan pengendara usia remaja. DBQ adalah instrumen pengukuran yang digunakan secara luas untuk menilai aspek perilaku pengemudi yang mencerminkan kesalahan dari sisi pengendara, penyimpangan yang dilakukan, dan tindakan berisiko yang disengaja dilakukan. DBQ dikembangkan pada tahun 1990an sebagai alat untuk menilai perilaku mengemudi yang menyimpang (Parker, Reason, Manstead, \& Stradling, 1995);(Reason, Manstead, Stradling, Baxter, \& Campbell, 1990).

Beberapa studi telah dilakukan untuk mengetahui perilaku pengemudi dengan questionaire Profil Perilaku Pengemudi. Kirytopoulos, Kazaras, Papapavlou, Ntzeremes, and Tatsiopoulos (2017) telah melakukan studi kebiasaan mengemudi dan persepsi keselamatan 
jalan pada segmen jalan berupa trowongan jalan (tunnel), dari hasil studi ini mereka mendapatkan kesimpulan bahwa banyak pengguna jalan yang memiliki beberapa kesalahpahaman mengenai sikap yang direkomendasikan baik dalam situasi normal dan kritis di dalam tunnel. Dari informasi maka dapat dengan segera dilakukan tindakan berupa penyuluhan maupun kampanye tentang keselamatan jalan dan apa yang harus dilakukan pada saat kritis di dalam tunnel. Hassan, Shawky, Kishta, Garib, and Al-Harthei (2017) Meneliti faktor-faktor yang mempengaruhi kepatuhan driver terhadap peraturan tentang kecepatan kendaraan. Penelitian ini mendapatkan hasil bahwa kebanyakan pengendara melanggar kecepatan karena hanya ada sedikit rambu kecepatan dan rendahnya penegakan peraturan oleh kepolisian. Dalam hal ini masalah pelanggaran kecepatan lalu lintas dapat diatasi dengan memperhatikan dua isu tersebut. Sedangkan Nabipour, Nakhaee, Khanjani, Moradlou, and Sullman (2015) menggunakan questionnaire profil perilaku pengemudi dengan tujuan utama untuk menyelidiki sifat psikometrik dari remaja pengguna jalan sebagai alat untuk mengukur potensi perilaku berisiko di jalan di Iran. Pada penelitian ini ditemukan kesimpulan bahwa murid lelaki lebih sering terlibat dalam perilaku berkendara beresiko dibandingkan murid perempuan dan bahwa murid di daerah perkotaan ditemukan lebih cenderung berperilaku dengan cara yang tidak aman atau berisiko di jalan.penelitian ini mengungkapkan perlunya intervensi, seperti pendidikan dan penegakan hukum untuk meningkatkan budaya keselamatan di jalan antara remaja Iran.

Diperlukan studi tentang sifat menyimpang / penyimpangan yang paling sering dilakukan pengguna jalan ketika berkendara sehingga dapat dilakukan penyuluhan dan kampanye yang akan dilaksanakan dengan pihak kepolisian untuk menurunkan tingkat pelanggaran pengguna jalan. Selain itu perlu dilakukan kajian mengenai apakah kampanye yang dilakukan pihak terkait yang mengusung persepsi tentang rasa takut mengalami kecelakaan akan berpengaruh dalam merubah keterampilan berkendara pengemudi usia remaja.

\section{METODOLOGI PENELITIAN}

Pengambilan data dalam penelitian ini menggunakan kuesioner untuk mengetahui pendapat, persepsi, dan pengalaman responden dengan tujuan mengetahui sifat dan karakteristik responden pengendara usia remaja dalam berkendara. Data diperoleh melalui kuesioner yang ditujukan untuk pengendara remaja dengan usia dibawah 18 tahun. Sebanyak 272 peserta menyelesaikan kuesioner di ruang kelas mereka selama jam sekolah. Sampel diambil dari 6 sekolah menengah di wilayah Semarang yang terdiri dari responden perempuan sebanyak $63 \%$ dan responden laki-laki sebanyak $37 \%$ dengan rentang usia antara 15 hingga 18 tahun. Jenis kuesioner yang digunakan adalah The Driver Behaviour Questionnaire(DBQ), kuesioner tersebut memiliki tiga puluh item pernyataan sehubungan dengan perilaku dan keterampilan berkendara, dengan peserta diminta untuk menanggapi setiap item dengan menunjukkan seberapa sering mereka berperilaku seperti ditunjukkan. Responden pengendara kendaraan usia remaja akan diminta untuk melengkapi kuesioner perilaku pengemudi (DBQ) yang meminta mereka untuk menilai frekuensi dimana mereka melakukan berbagai jenis kesalahan dan pelanggaran saat berkendara. Selain itu responden juga diminta untuk mengisi kuesioner tentang persepsi terhadap keselamatan jalan dan persepsi terhadap rasa takut saat berkendara.

Hasil Kuesioner DBQ yang telah diisi responden kemudian akan dianalisis dengan metode analisis regresi yang dibantu dengan software Stastistical Packages for Sosial Sciences (SPSS) 16.0. Analisis regresi dipilih karena dalam penelitian ini akan mencari hubungan antara dua variabel penelitian yaitu variabel kriterium (Perilaku Pengemudi) dan variabel prediktor (Persepsi terhadap rasa takut) yang memiliki bentuk hubungan linier. Pada 
penelitian ini profil sikap pengguna jalan usia remaja seperti eror lapses violations mistake akan diukur, serta dadicari hubungan sikap pengendara dengan kecenderungan dalam mengalami kecelakaan lalu lintas.

\section{HASIL DAN PEMBAHASAN}

Tabel 1 menampilkan ranking dari seluruh item pertanyaan DBQ dilihat dari nilai means dan standard deviations. Dapat dilihat bahwa sample group ini lebih sering melakukan tindakan dari kategori error dan lapses, daripada melakukan tindakan yang dikategorikan sebagai ordinary violation atau pelanggaran umum. Selain itu kategori tindakan yang paling jarang dilakukan pengemudi usia remaja yaitu aggressive violations atau pelanggaran agresif.

Tabel 1. Item pertanyaan DBQ diranking dari nilai means

\begin{tabular}{|c|c|c|c|c|}
\hline $\begin{array}{l}\text { Q } \\
\text { no }\end{array}$ & Item & Mean & $\begin{array}{l}\text { Std. } \\
\text { Deviation }\end{array}$ & Variance \\
\hline 26 & $\begin{array}{l}\text { Saya membunyikan klakson saat merasa } \\
\text { terganggu dengan pengguna jalan lain }\end{array}$ & 4.9559 & 0.23893 & 0.057 \\
\hline 20 & $\begin{array}{l}\text { Saya menyalip / mendahului pengendara lain dari } \\
\text { jalur kiri }\end{array}$ & 4.5846 & 0.71374 & 0.509 \\
\hline 8 & $\begin{array}{l}\text { Saya menyadari bahwa saya tidak terlalu ingat } \\
\text { tentang jalan yang baru saja saya lalui }\end{array}$ & 4.5699 & 0.82996 & 0.689 \\
\hline 2 & $\begin{array}{l}\text { Saya bermaksud untuk berkendara ke tujuan A, } \\
\text { tetapi tiba-tiba tersadar anda sedang dijalan } \\
\text { menuju tujuan B }\end{array}$ & 4.5147 & 0.71345 & 0.509 \\
\hline 16 & $\begin{array}{l}\text { Saya tidak memperhatikan kecepatan kendaraan } \\
\text { yang akan disalip }\end{array}$ & 4.4191 & 0.74453 & 0.554 \\
\hline 17 & $\begin{array}{l}\text { Saya keluar dari persimpangan dengan cepat- } \\
\text { cepat sehingga pengendara lain akan memberikan } \\
\text { jalan }\end{array}$ & 4.4118 & 0.81018 & 0.656 \\
\hline 6 & $\begin{array}{l}\text { Saya lupa dimana memarkir kendaraan anda di } \\
\text { tempat parkir }\end{array}$ & 4.3382 & 0.89871 & 0.808 \\
\hline 23 & $\begin{array}{l}\text { Saya menerobos lampu lalu lintas yang baru saja } \\
\text { berubah }\end{array}$ & 4.2941 & 0.89375 & 0.799 \\
\hline 21 & $\begin{array}{l}\text { Saya memacu kendaraan saat lampu menyala } \\
\text { hijau di traffic light dengan maksud mengalahkan } \\
\text { pengemudi di samping Anda }\end{array}$ & 4.2831 & 0.9395 & 0.883 \\
\hline 24 & Saya mengabaikan batas kecepatan di jalan & 4.2794 & 0.79381 & 0.63 \\
\hline 4 & $\begin{array}{l}\text { Saya salah menyalakan sesuatu, misalnya tombol } \\
\text { lampu, saat bermaksud menyalakan benda lain } \\
\text { misal lampu sign }\end{array}$ & 4.2647 & 0.83939 & 0.705 \\
\hline 7 & $\begin{array}{l}\text { Di bundaran/persimpangan, saya salah berbelok } \\
\text { ke jalan yang bukan saya tuju }\end{array}$ & 4.2574 & 0.80126 & 0.642 \\
\hline 9 & $\begin{array}{l}\text { Saat mengantri untuk masuk ke jalan utama saya } \\
\text { terlalu fokus dengan keadaan lalu lintas dijalan } \\
\text { utama tersebut sampai saya hampir menabrak } \\
\text { kendaraan di depan saya }\end{array}$ & 4.1985 & 1.01879 & 1.038 \\
\hline 18 & $\begin{array}{l}\text { Saya mengabaikan batas kecepatan di jalan } \\
\text { perumahan }\end{array}$ & 4.1875 & 0.95167 & 0.906 \\
\hline 11 & $\begin{array}{l}\text { Saya lupa tidak memeriksa spion belakang saat } \\
\text { hendak menjalankan kendaraan maupun saat } \\
\text { berganti jalur }\end{array}$ & 4.1765 & 0.98237 & 0.965 \\
\hline 5 & $\begin{array}{l}\text { Saya mencoba memacu kendaraan untuk } \\
\text { mengindari lampu lalulintas berubah merah } \\
\text { dengan gigi tiga }\end{array}$ & 4.1728 & 0.83926 & 0.704 \\
\hline 12 & $\begin{array}{l}\text { Saya mengerem terlalu cepat pada jalanan yang } \\
\text { licin sehingga tergelincir }\end{array}$ & 4.1287 & 0.82957 & 0.688 \\
\hline
\end{tabular}




\begin{tabular}{|c|c|c|c|c|}
\hline $\begin{array}{l}\text { Q } \\
\text { no }\end{array}$ & Item & Mean & $\begin{array}{l}\text { Std. } \\
\text { Deviation }\end{array}$ & Variance \\
\hline 3 & 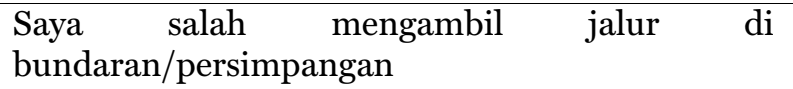 & 4.1213 & 0.95854 & 0.919 \\
\hline 22 & $\begin{array}{l}\text { Saya berkendara dengan jarak sangat dekat } \\
\text { dengan kendaraan di depan sehingga sulit untuk } \\
\text { berhenti pada saat terjadi keadaan darurat }\end{array}$ & 4.1029 & 0.95492 & 0.912 \\
\hline 28 & $\begin{array}{l}\text { Saya menjadi marah dengan tipe pengemudi } \\
\text { tertentu } \quad \text { dan } \\
\text { permusuhan/kemarahan Anda dengan cara apa } \\
\text { pun yang Anda bisa }\end{array}$ & 4.0699 & 1.00492 & 1.01 \\
\hline 15 & $\begin{array}{l}\text { Saya mencoba untuk menyalip pengendara yang } \\
\text { tidak Anda perhatikan telah memberi isyarat } \\
\text { lampu sign untuk berbelok }\end{array}$ & 3.9926 & 0.97947 & 0.959 \\
\hline 19 & $\begin{array}{l}\text { Saya tetap di jalur jalan yang Anda tahu akan } \\
\text { ditutup sampai detik terakhir sampai terpaksa } \\
\text { berpindah jalur }\end{array}$ & 3.989 & 0.99624 & 0.992 \\
\hline 1 & $\begin{array}{l}\text { Saat melakukan putar balik, saya pernah } \\
\text { menabrak sesuatu karena tidak melihatnya }\end{array}$ & 3.9743 & 0.96588 & 0.933 \\
\hline 13 & $\begin{array}{l}\text { Saat berbelok ke kanan, saya hampir menabrak } \\
\text { pesepeda yang datang dari sebelah kanan }\end{array}$ & 3.9669 & 0.95798 & 0.918 \\
\hline 14 & $\begin{array}{l}\text { Saya lalai melihat tanda "beri jalan" dan nyaris } \\
\text { menghindari bertabrakan dengan pengendara } \\
\text { yang memiliki hak jalan }\end{array}$ & 3.9559 & 0.9556 & 0.913 \\
\hline 27 & $\begin{array}{l}\text { Saya menjadi marah terhadap pengendara lain } \\
\text { dan mengejar pengendara tersebut untuk } \\
\text { memarahinya }\end{array}$ & 3.636 & 1.0849 & 1.177 \\
\hline 10 & $\begin{array}{l}\text { Saya tidak melihat pejalan kaki yang sedang } \\
\text { menyeberang ketika sedang menepikan kendaraan } \\
\text { saya }\end{array}$ & 3.5074 & 0.9907 & 0.981 \\
\hline 25 & Saya berkendara saat mabuk & 3.0331 & 1.15049 & 1.324 \\
\hline
\end{tabular}

Berdasarkan dari nilai mean pada kuesioner DBQ didapatkan tiga tindakan yang paling sering dilakukan oleh pengendara usia remaja yaitu 'membunyikan klakson saat merasa terganggu dengan pengguna jalan lain' yang dikategorikan sebagai lapses, 'menyalip / mendahului pengendara lain dari jalur kiri' yang dikategorikan sebagai pelanggaran umum, dan 'menyadari bahwa saya tidak terlalu ingat tentang jalan yang baru saja saya lalui' yang merupakan kategori tindakan error. Sementara itu tiga tindakan yang paling jarang dilakukan oleh sampel group ini adalah 'menjadi marah terhadap pengendara lain dan mengejar pengendara tersebut untuk memarahinya', 'tidak melihat pejalan kaki yang sedang menyeberang ketika sedang menepikan kendaraan', serta 'berkendara saat mabuk' yang secara berurutan dikategorikan sebagai Aggressive Violation, Ordinary violations dan Error.

Tabel 2. Hubungan rasa takut dengan keterampilan berkendara secara keseluruhan

\begin{tabular}{cllc}
\hline Model R & R Square & $\begin{array}{l}\text { Adjusted } \\
\text { Square }\end{array}$ & $\begin{array}{c}\text { R Std. Error of } \\
\text { the Estimate }\end{array}$ \\
\hline $.105^{\mathrm{a}}$ & .011 & .007 & 12.285 \\
\hline
\end{tabular}


Tabel 3. Hubungan rasa takut dengan setiap jenis kesalahan dalam berkedara

\begin{tabular}{llll} 
Perilaku & $\mathrm{R}$ & R Square & Std. Error of the Estimate \\
\hline Lapses & $.057^{\mathrm{a}}$ & .003 & 4.14965 \\
\hline Error & $.083^{\mathrm{a}}$ & .007 & 3.90859 \\
\hline $\begin{array}{l}\text { Ordinary } \\
\text { Violations }\end{array}$ & $.108^{\mathrm{a}}$ & .012 & 4.77139 \\
$\begin{array}{l}\text { Aggressive } \\
\text { Violation }\end{array}$ & $.102^{\mathrm{a}}$ & .010 & 2.09031 \\
\hline
\end{tabular}

Dalam hal hubungan antara rasa takut dengan keterampilan mengemudi, yang direpresentasikan pada kuesioner DBQ, didapatkan bahwa persepsi rasa takut hanya berpengaruh kecil pada keterampilan mengemudi pengendara usia remaja yaitu sebesar $1.1 \%$ yang ditunjukan pada tabel 2 . Hal ini berarti bahwa walaupun pengendara telah memiliki persepsi rasa takut yang besar terhadap kecelakaan yang mungkin terjadi, namun tidak serta merta membuat keterampilan mengemudi pasa grup ini menjadi lebih baik. Namun lebih jauh lagi, terlihat dari tabel 3, apabila dilakukan breakdown terhadap keterampilan mengemudi yang dibagi menjadi empat kategori kesalahan dalam mengemudi, yaitu lapses, error, ordinary violation, dan aggressive violation, terlihat bahawa persepsi terhadap rasa takut mengalami kecelakaan memiliki hubungan yang paling besar terhadap dua tipe kategori pelanggaran yaitu ordinary violations dan aggressive violations sebesar $1,2 \%$ dan $1 \%$ dibandingkan dengan tipe pelanggaran lapses dan eror yang hanya sebesar $0.3 \%$ dan $0.7 \%$.

Hal ini membuktikan bahwa walaupun persepsi terhadap rasa takut tidak berpengaruh besar terhadap keterampilan mengemudi secara keseluruhan dan tidak dapat mengurangi tingkat kesalahan pengendara (lapses dan eror), namun dapat mengurangi niatan pengemudi untuk melakukan pelanggaran baik pelanggaran ringan maupun pelanggaran berat (ordinary dan aggressive violations).

\section{SIMPULAN DAN SARAN}

Tiga tindakan yang paling sering dilakukan oleh pengendara usia remaja yaitu 'membunyikan klakson saat merasa terganggu dengan pengguna jalan lain', 'menyalip / mendahului pengendara lain dari jalur kiri', dan 'menyadari bahwa saya tidak terlalu ingat tentang jalan yang baru saja saya lalui' yang secara berurutan dikategorikan sebagai lapses, ordinary violation, dan error. Sementara itu tiga tindakan yang paling jarang dilakukan oleh sampel group ini adalah 'menjadi marah terhadap pengendara lain dan mengejar pengendara tersebut untuk memarahinya', 'tidak melihat pejalan kaki yang sedang menyeberang ketika sedang menepikan kendaraan', serta 'berkendara saat mabuk' yang secara berurutan dikategorikan sebagai Aggressive Violation, Ordinary violations dan Error.

Persepsi terhadap rasa takut tidak memiliki hubungan yang cukup kuat terhadap keterampilan mengemudi pengendara usia remaja terlihat dari nilai korelasi Rsquare kedua variabel tersebut yaitu sebesar $1.1 \%$. Selain itu persepsi rasa takut yang juga tidak dapat serta merta mengurangi tingkat kesalahan yang dapat dibuat tiap individu saat sedang berkendara (lapses dan error), tetapi perasaan takut ini dapat mengurangi intensi atau keinginan pengendara remaja untuk melakukan tindakan pelanggaran ringan maupun berat (ordinary dan aggressive violations). Sehingga dalam hal tindakan intervensi untuk mengurangi nilai kecelakan lalu lintas, program yang dapat dilakukan selain kampanye untuk meningkatkan kesadaran diri adalah dengan menanamkan rasa takut terhadap kecalakan lalu lintas. Selain 
itu juga perlu dilakukan pelatihan tentang keterampilan dan aturan - aturan umum dalam berkedara secara aman dan tertib.

\section{DAFTAR PUSTAKA}

Coleman, N. V., Williams, P., Morales, A. C., \& White, A. E. (2017). Attention, attitudes, and action: When and why incidental fear increases consumer choice. Journal of Consumer Research, 44(2), 283-312.

D'Souza, C., \& Tay, R. (2016). Advertising implications and design of messages. Marketing Intelligence and Planning, 34(4), 504 - 522. doi:https:// dx.doi.org/10.1108/MIP-03-20150069

Elliott, M. A., \& Baughan, C. J. (2004). Developing a Self-Report Method for Investigating Adolescent Road User Behaviour. Transport. Res. Part F: Traffic Psychol. Behav. 7, 373-393.

Hassan, H. M., Shawky, M., Kishta, M., Garib, A. M., \& Al-Harthei, H. A. (2017). Investigation of drivers' behavior towards speeds using crash data and self-reported questionnaire. Accident Analysis \& Prevention, 98, 348-358.

Kirytopoulos, K., Kazaras, K., Papapavlou, P., Ntzeremes, P., \& Tatsiopoulos, I. (2017). Exploring Driving Habits and Safety Critical Behavioural Intentions among Road Tunnel Users: a Questionnaire Survey in Greece. Tunnelling and Underground Space Technology, 63, 244251.

Klauer, S. G., Simons-Morton, B. G., Lee, S. E., Ouimet, M. C., Howard, E. H., \& Dingus, T. A. (2011). Novice Drivers' Exposure to Known Risk Factors during The First 18 Months of Licensure: The Effect of Vehicle Ownership. Traffic Injury Prevention, 12(2), 159-168.

Lu, J., Xie, X., \& Zhang, R. (2013). Focusing on Appraisals: How and Why Anger and Fear Influence Driving Risk Perception. Journal of safety research, 45, 65-73.

Mosedale, J., Purdy, A., \& Clarkson, E. (2004). Contributory Factors to Road Accidents. London: Department of Transportation.

Mowen, J., Harris, E. G., \& Bone, S. A. (2004). Personality Traits and Fear Response to Print Advertisements: Theory and an Empirical Study. Psychology and Marketing, 21(11), 927-943.

Nabipour, A. R., Nakhaee, N., Khanjani, N., Moradlou, H. Z., \& Sullman, M. J. (2015). The Road User Behaviour of School Students in Iran. Accident Analysis \& Prevention, 75, 43-54.

Parker, D., Reason, J. T., Manstead, A. S. R., \& Stradling, S. G. (1995). Driving errors, driving violations and accident involvement. Ergonomics, 38(5), 1036-1048.

Passyn, K., \& Sujan, M. (2006). Self-Accountability Emotions and Fear Appeals: Motivating Behavior. Journal of Consumer Research, 32(4), 583-589. doi:https://dx.doi.org/10.1086/500488

Petridou, E., \& Moustaki, M. (2001). Human Factors in The Causation of Road Traffic Crashes. Eur. J. Epidemiol, 16, 819-826. doi:http://dx.doi.org/10.1023/A.;1; 1007649804201

Pignataro, J. L. (1973). Traffic Engineering Theory and Practice. USA: PrenticeHall, inc.

Poudel-Tandukar, K., Nakahara, S., Ichikawa, M., Poudel, K. C., \& Wakai, S. (2006). Relationship Between Mechanisms and Activities at The Time Of Pedestrian Injury and Activity Limitation Among School Adolescents in Kathmandu, Nepal

Accid. Anal. Prev. 38, 1058-1063.

Reason, J., Manstead, A., Stradling, S., Baxter, J., \& Campbell, K. (1990). Errors and Violations on The Roads: A Real Distinction? Ergonomics, 33(10-11), 1315-1332.

Schmidt-Daffy, M. (2013). Fear and Anxiety While Driving: Differential Impact of Task Demands, Speed And Motivation. Transportation Research, 16, 14-28.

Simons-Morton, B. G., Ouimet, M. C., Zhiwei, Z., Lee, S. L., Klauer, S. E., Wang, J., . . Dingus, T. E. (2011). Risky Driving Among Novice Teenagers and Their Parents. American Journal of Public Health, 101(12), 2362-2367.

Siska, \& Cokki. (2017). Pengaruh Sifat Dasar terhadap Respon Rasa Takut pada Iklan Keselamatan Berkendara. Conference on Management and Behavioral Studies.

Sullman, M. J., \& Mann, H. N. (2009). The Road User Behaviour of New Zealand Adolescents. Transport. Res. Part F: Traffic Psychol. Behav. 12, 494-502.

Sullman, M. J., Thomas, A., \& Stephens, A. N. (2012). The road user behaviour of school students in Belgium. Accid. Anal. Prev. 48, 495-504. 
Surya, A. Z., \& Bagaskara, S. (2016). Pengaruh Emosi Takut terhadap Persepsi Risiko pada Pengendara Motor: Studi Menggunakan Simulator. Simposium XIX FSTPT Universitas Islam Indonesia.

Tight, M. (2012). Course on Sustainable Transport Policy. Birmingham, United Kingdom: University of Birmingham.

\section{LAMPIRAN}

\section{KUESIONER PENELITIAN}

\section{Driver Behaviour Questionnaire}

\begin{tabular}{|c|c|c|c|c|c|c|}
\hline \multirow[b]{2}{*}{ NO } & \multirow[b]{2}{*}{ PERNYATAAN } & \multicolumn{5}{|c|}{ JAWABAN } \\
\hline & & $\begin{array}{c}\text { Tidak } \\
\text { pernah }\end{array}$ & $\begin{array}{l}\text { Hampir } \\
\text { tidak } \\
\text { Pernah }\end{array}$ & $\begin{array}{l}\text { Kadang- } \\
\text { kadang }\end{array}$ & Sering & Selalu \\
\hline 1 & $\begin{array}{l}\text { Saat melakukan putar balik, saya pernah } \\
\text { menabrak sesuatu karena tidak melihatnya }\end{array}$ & & & & & \\
\hline 2 & $\begin{array}{l}\text { Saya bermaksud untuk berkendara ke tujuan A, } \\
\text { tetapi tiba-tiba tersadar anda sedang dijalan } \\
\text { menuju tujuan B }\end{array}$ & & & & & \\
\hline 3 & Saya berkendara saat mabuk & & & & & \\
\hline 4 & $\begin{array}{l}\text { Saya salah mengambil jalur di } \\
\text { bundaran/persimpangan }\end{array}$ & & & & & \\
\hline 5 & $\begin{array}{l}\text { Saat mengantri untuk masuk ke jalan utama saya } \\
\text { terlalu fokus dengan keadaan lalu lintas dijalan } \\
\text { utama tersebut sampai saya hampir menabrak } \\
\text { kendaraan di depan saya }\end{array}$ & & & & & \\
\hline 6 & $\begin{array}{l}\text { Saya tidak melihat pejalan kaki yang sedang } \\
\text { menyeberang ketika sedang menepikan } \\
\text { kendaraan saya }\end{array}$ & & & & & \\
\hline 7 & $\begin{array}{l}\text { Saya membunyikan klakson saat merasa } \\
\text { terganggu dengan pengguna jalan lain }\end{array}$ & & & & & \\
\hline 8 & $\begin{array}{l}\text { Saya lupa tidak memeriksa spion belakang saat } \\
\text { hendak menjalankan kendaraan maupun saat } \\
\text { berganti jalur }\end{array}$ & & & & & \\
\hline 9 & $\begin{array}{l}\text { Saya mengerem terlalu cepat pada jalanan yang } \\
\text { licin sehingga tergelincir }\end{array}$ & & & & & \\
\hline 10 & $\begin{array}{l}\text { Saya keluar dari persimpangan dengan cepat- } \\
\text { cepat sehingga pengendara lain akan } \\
\text { memberikan jalan }\end{array}$ & & & & & \\
\hline 11 & $\begin{array}{l}\text { Saya mengabaikan batas kecepatan di jalan } \\
\text { perumahan }\end{array}$ & & & & & \\
\hline 12 & $\begin{array}{l}\text { Saya salah menyalakan sesuatu, misalnya tombol } \\
\text { lampu, saat bermaksud menyalakan benda lain } \\
\text { misal lampu sign }\end{array}$ & & & & & \\
\hline
\end{tabular}




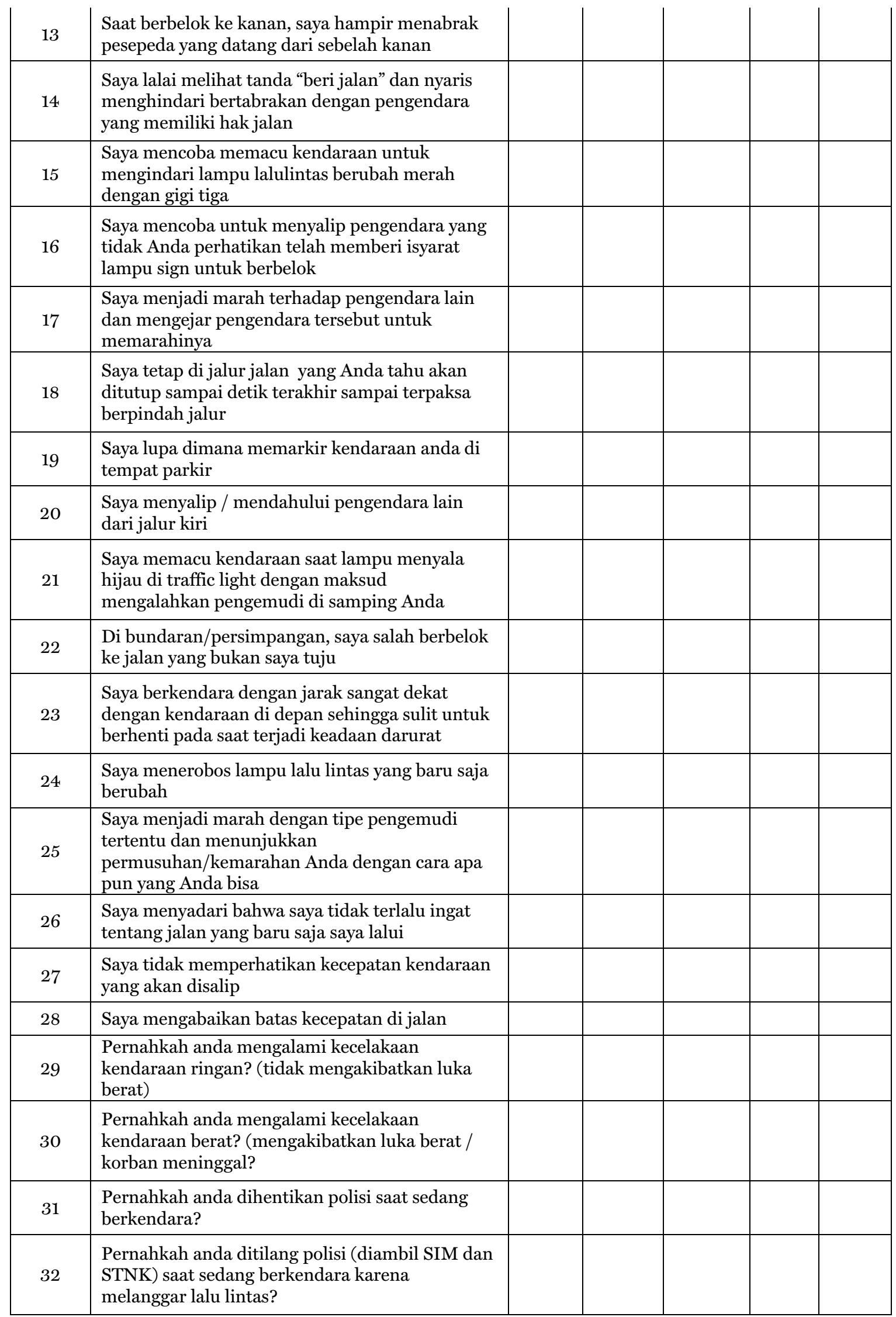




\begin{tabular}{|c|l|l|l|l|l|}
33 & $\begin{array}{l}\text { Pernahkan anda menabrak pengendara lain di } \\
\text { jalan? }\end{array}$ & & & & \\
\hline 34 & $\begin{array}{l}\text { Pernahkan ada ditabrak pengendara lain saat } \\
\text { sedang mengendarai kendaraan anda? }\end{array}$ & & & & \\
\hline
\end{tabular}

\section{Persepsi Mahasiswa Terhadap Rasa Takut}

\begin{tabular}{|c|c|c|c|c|c|c|}
\hline \multirow[b]{2}{*}{ NO } & \multirow[b]{2}{*}{ PERNYATAAN } & \multicolumn{5}{|c|}{ JAWABAN } \\
\hline & & $\begin{array}{l}\text { Sangat } \\
\text { Setuju }\end{array}$ & Setuju & $\begin{array}{l}\text { Ragu- } \\
\text { ragu }\end{array}$ & $\begin{array}{l}\text { Tidak } \\
\text { Setuju }\end{array}$ & $\begin{array}{l}\text { Sangat } \\
\text { Tidak } \\
\text { Setuju }\end{array}$ \\
\hline 1 & $\begin{array}{l}\text { Saya merasa takut ketika sepeda motor saya } \\
\text { menabrak kendaraan lain }\end{array}$ & & & & & \\
\hline 2 & $\begin{array}{l}\text { Saya takut akan terjadi kecelakaan ketika saya } \\
\text { mengemudi dalam kondisi fisik yang kurang baik }\end{array}$ & & & & & \\
\hline 3 & $\begin{array}{l}\text { Meskipun saya sudah mengemudikan kendaraan } \\
\text { dengan hati-hati, saya masih merasa takut } \\
\text { terhadap keselamatan diri saya }\end{array}$ & & & & & \\
\hline 4 & $\begin{array}{l}\text { Saya merasa takut ketika berpindah lajur tanpa } \\
\text { menyalakan lampu sein }\end{array}$ & & & & & \\
\hline 5 & $\begin{array}{l}\text { Saya takut membuat orang lain cedera/luka } \\
\text { ketika saya mengendarai sepeda motor dengan } \\
\text { kecepatan tinggi (ngebut) }\end{array}$ & & & & & \\
\hline 6 & $\begin{array}{l}\text { Saya takut mengalami kecelakaan jika merebos } \\
\text { lampu merah }\end{array}$ & & & & & \\
\hline 7 & $\begin{array}{l}\text { Tidak adanya kaca spion pada sepeda motor } \\
\text { meningkatkan rasa takut saya akan kecelakaan }\end{array}$ & & & & & \\
\hline 8 & $\begin{array}{l}\text { Meskipun keadaan saya tidak sehat saat } \\
\text { berkendara, saya tidak takut mengalami } \\
\text { kecelakaan }\end{array}$ & & & & & \\
\hline 9 & $\begin{array}{l}\text { Saya tidak akan takut mengalami kecelakaan } \\
\text { ketika berkendara dalam kondisi emosi }\end{array}$ & & & & & \\
\hline 10 & $\begin{array}{l}\text { Saya takut mengendarai sepeda motor pada } \\
\text { malam hari dengan kondisi penerangan jalan } \\
\text { yang kurang }\end{array}$ & & & & & \\
\hline
\end{tabular}

